\title{
Surveillance trends of the 2009 influenza A(H1N1) pandemic in Europe
}

A Amato-Gauci (andrew.amato@ecdc.europa.eu) ${ }^{1}$, P Zucs ${ }^{1}$, R Snacken ${ }^{1}$, B Ciancio ${ }^{1}$, V Lopez ${ }^{1}$, E Broberg ${ }^{1}$, P Penttinen ${ }^{1}$, A Nicoll ${ }^{1}$, on behalf of the European Influenza Surveillance Network (EISN) ${ }^{2}$

1. European Centre for Disease Prevention and Control, Stockholm, Sweden

2. The members of the network are listed at the end of the article

Citation style for this article:

Amato-Gauci A, Zucs P, Snacken R, Ciancio B, Lopez V, Broberg E, Penttinen P, Nicoll A, on behalf of the European Influenza Surveillance Network (EISN). Surveillance trends of the 2009 influenza $\mathrm{A}\left(\mathrm{H}_{1} \mathrm{~N}_{1}\right)$ pandemic in Europe.

Euro Surveill. 2011;16(26):pii=19903. Available online: http://www.eurosurveillance.org/ViewArticle.aspx?Articleld=19903

Article published on 30 June 2011

We describe the epidemiology and virology of the official length of the 2009 pandemic (68 weeks from April 2009 to August 2010) in the 27 European Union Member States plus Norway and Iceland. The main trends are derived from published literature as well as the analysis and interpretation of data provided to the European Centre for Disease Prevention and Control (ECDC) through the European Influenza Surveillance Network (EISN) and data collected by the ECDC itself. The 2009 influenza $A\left(\mathrm{H}_{1} \mathrm{~N}_{1}\right)$ pandemic started in Europe around week 16 of 2009 (although the World Health Organization (WHO) declared only in week 18). It progressed into an initial spring/ summer wave of transmission that occurred in most countries, but was striking only in a few, notably the United Kingdom. During the summer, transmission briefly subsided but then escalated again in early autumn, just after the re-opening of the schools. This wave affected all countries, and was brief but intense in most, lasting about 14 weeks. It was accompanied by a similar but slightly delayed wave of hospitalisations and deaths. By the time the WHO declared the pandemic officially over in August 2010 (week 32), Europe had experienced transmission at low level for about 34 weeks.

\section{Objectives}

This review article provides a broad epidemiological overview of the entire official period of 68 weeks of the 2009 pandemic, from week 18 (end April) 2009 to week 32 (mid-August) 2010, in the 27 European Union (EU) Member States plus Norway and Iceland (in the following called EU+2). It is linked to a more extensive document developed with the help of national surveillance experts that provides further background on influenza epidemics and pandemics, notably their variability and unpredictability [1]. The review also identifies some initial lessons learnt, especially relating to surveillance needs in a pandemic, as discussed and agreed at the annual expert meeting of the European Influenza Surveillance Network (EISN) held in Sofia, Bulgaria, in June 2010 [2].

\section{Data collection}

The main surveillance trends and information presented here are derived from epidemiological analyses of the primary care and virological data (Table 1 ) reported to the European Centre for Disease Prevention and Control (ECDC)'s European Surveillance System (TESSy) by the European Influenza Surveillance Network (EISN; for more information on this network see: http://ecdc. europa.eu/en/activities/surveillance/EISN/Pages/ home.aspx). Building on the existing reporting systems, new surveillance mechanisms were developed to meet additional needs for the pandemic, especially of capturing data on severe and fatal cases of influenza (Table 1). These were collected and reported in one of the Weekly Influenza Surveillance Overviews (WISO) published by ECDC during the pandemic [3,4].

Concurrently, epidemic intelligence [5] and targeted science watch methods (experts scan scientific journals and grey literature and summarise significant publications with public health relevance, significant developments or upcoming meetings) were employed to determine, as early as possible, the important parameters needed for risk assessment, adjusting projections and informing counter-measures in areas where the routine EU surveillance systems are less informative.

\section{Early pandemic}

Following its emergence in Mexico in March 2009 [6], the pandemic influenza $A\left(\mathrm{H}_{1} \mathrm{~N}_{1}\right)_{2009}$ virus appears to have started circulating in Europe around week 16 of 2009, initially in travellers returning from Mexico, or their direct contacts (Figures 1 and 2). Early on it was clear that this virus met the previously agreed criteria for a pandemic strain (see summary at: http://www.ecdc.europa.eu/en/healthtopics/ $\mathrm{H}_{1} \mathrm{~N}_{1} /$ Documents/100503_health_topics_pandemic_definition_of_a_pandemic.pdf). In response to the threat, EU/EEA countries started to submit detailed casebased reports to the ECDC in May 2009, using an ad hoc database hosted on the secure Early Warning and Response (EWRS) platform. The earliest validated date 
of onset of a European case was 19 April 2009 (week 16). When country representatives agreed in week 39 that central collection of case-based data was no longer justified, the database contained 11,275 individual records $(11,207$ of which were laboratory-confirmed) submitted by 28 countries. A detailed analysis of these first cases is available elsewhere [7].

The surveillance data, supplemented by the ECDC epidemic intelligence and targeted science watch activities, helped to quantify the main pandemic parameters resulting in a 'dynamic scientific risk assessment that was updated 10 times in 2009 as more information became available [8]. For example, the reproductive number $R_{0}$ for the infection was estimated with $95 \%$ confidence intervals between 1.1 and 1.4 [9] (95\% confidence interval) [9], a serial interval between 2.2 and 2.3 days [10], a mean generation time between 2.5 and 3 days [9] and a mean incubation period of 1.5 to 2 days. These figures are consistent with those found for previously circulating influenza strains [9].

There was a paucity of reliable data early on but even so, organisations such as the ECDC and WHO agreed that this was not a severe pandemic. For example, the ECDC interim risk assessment issued on 12 June 2009 [8] concluded:

"The current ECDC threat assessment for Europe is that the new influenza $A\left(H_{1} N_{1}\right) v$ virus will continue to spread. Though it seems that most of those infected in the US and in Europe experience a mild and self-limiting infection, this picture is still unclear as there has not been enough transmission to judge the effects, especially in those more at risk."
The pandemic waves spring/ summer and autumn/winter

Following the detection of the initial cases imported from North America into Europe, there was a spring and summer wave of transmission in Europe which affected most countries. Figure 1 shows the weekly percentage of influenza-like illness (ILI) notifications over the total number of reports throughout the whole reporting period, accumulated for all reporting countries. However, the wave and burden on the health services was only striking in very few European countries, especially the United Kingdom (UK) $[11,12]$ and to a lesser extent Spain [13].Transmission subsided as the summer progressed, in temporal association with the closure of schools $[12,14]$. However, transmission accelerated again following the re-opening of the schools, this time affecting all countries, as an early autumn/winter wave started around week 43 of 2009 (Figures 1 and 3) and progressed from west to east across the EU. The modal peak week for the 24 countries consistently reporting their sentinel ILI consultations in the season 2009/10 was week 48, 2009 (six countries), as opposed to week 4, 2009 (seven countries) for the previous season 2008/09. In most countries, the autumn/winter wave of disease was short and intense, lasting about 14 weeks and resembling the epidemic curve seen in the 1957 pandemic in Europe [15].

A similar wave of hospitalisations and deaths followed soon after (Figure 4), although these data on deaths and especially hospitalisation are less readily available because surveillance of severe disease attributable to influenza is not routine in most countries. For the whole pandemic period of 68 weeks (week 18, 2009 to week 35,2010 ), the EISN experts reported 925,861 cases of ILI (25 reporting countries) and 7,202,014 cases of acute respiratory infections (ARI) (16 reporting countries) attending their clinics. This is just a small proportion of the true number of cases in the

TABLE 1

Data collected for the EU+2 Weekly Influenza Surveillance Overview

\begin{tabular}{|l|l|}
\hline Type of data & Includes \\
\hline $\begin{array}{l}\text { Sentinel syndromic surveillance of influenza-like } \\
\text { illness (ILI)/acute respiratory infection (ARI) }\end{array}$ & $\begin{array}{l}\text { Subjective assessment of intensity and degree of geographic spread as well as reporting } \\
\text { of aggregated cases }\end{array}$ \\
\hline $\begin{array}{l}\text { Virological surveillance } \\
\text { Hospital sentinel surveillance of severe acute } \\
\text { respiratory infection (SARI) }\end{array}$ & $\begin{array}{l}\text { Laboratory data of the results of tests requested by sentinel physicians, and of tests done } \\
\text { on non-sentinel respiratory specimens collected, describing virus type and subtype, the } \\
\text { predominant strains, their antigenic and genetic characteristics and antiviral susceptibility }\end{array}$ \\
\hline Influenza deaths & $\begin{array}{l}\text { Case-based data of the more severe forms of acute respiratory infection including } \\
\text { influenza and other causes }\end{array}$ \\
\hline Qualitative reporting & $\begin{array}{l}\text { Both case-based deaths resulting from SARI and aggregated deaths reported by the } \\
\text { countries }\end{array}$ \\
\hline & $\begin{array}{l}\text { Planned to become the principle routine data to be collected should surveillance systems } \\
\text { become overwhelmed and unable to generate the other data: includes subjective } \\
\text { assessment of geographic spread, intensity, trend (as for ILI and ARI above), and impact }\end{array}$ \\
\hline
\end{tabular}

EU+2: the 27 European Union (EU) Member States plus Norway and Iceland.

a This was complemented by active monitoring of official national public health websites for announcements of deaths (see Figure 4).

${ }^{b}$ It was not necessary to activate this element.

Source: [3]. 


\section{FIGURE 1}

Percentage of weekly reported sentinel ILI caseload of the overall reports, cumulated for 25 EU+2 countries, week 40, 2008week 34, 2010

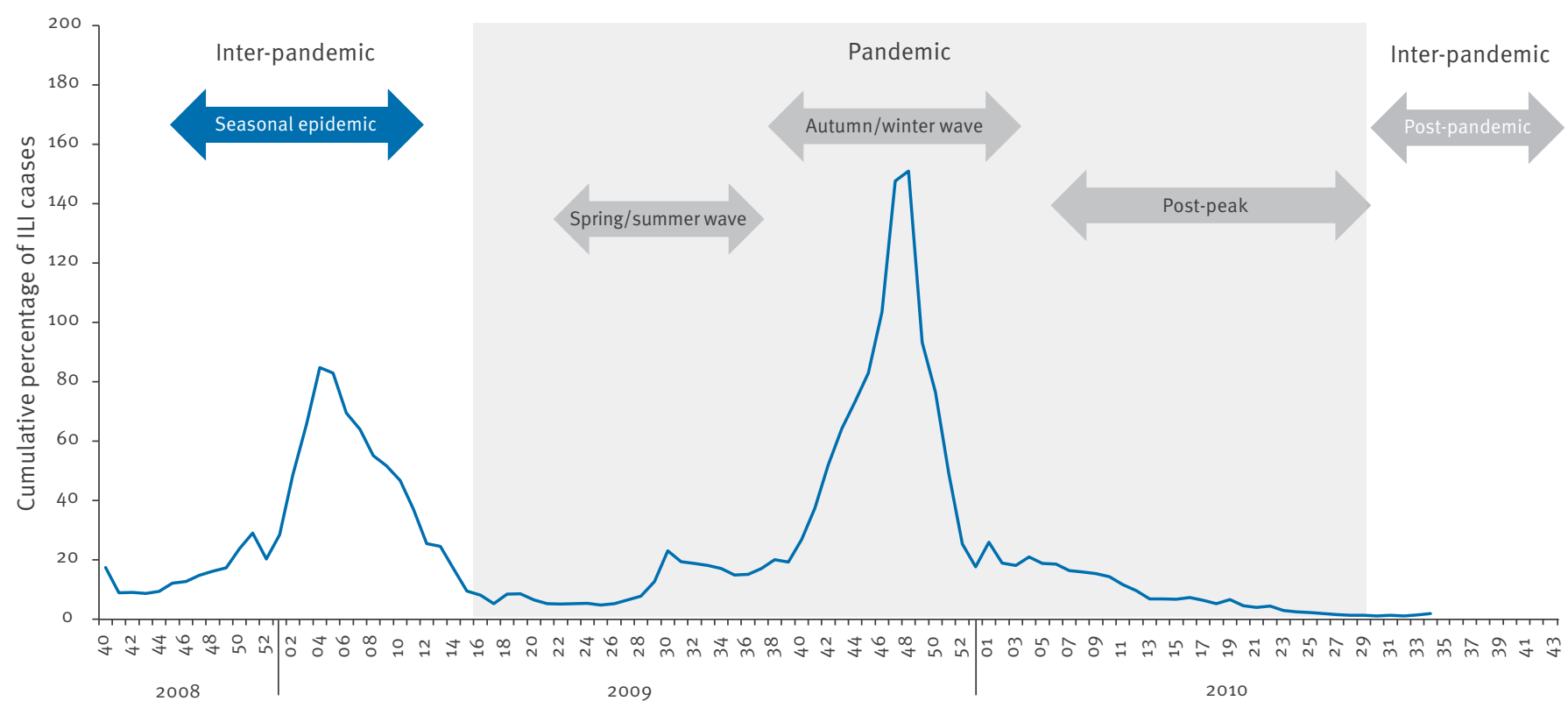

\section{FIGURE 2}

Distribution of the number of sentinel samples submitted and the percentage found positive for influenza, 28 EU+2 countries, seasons 2008/09-2009/10

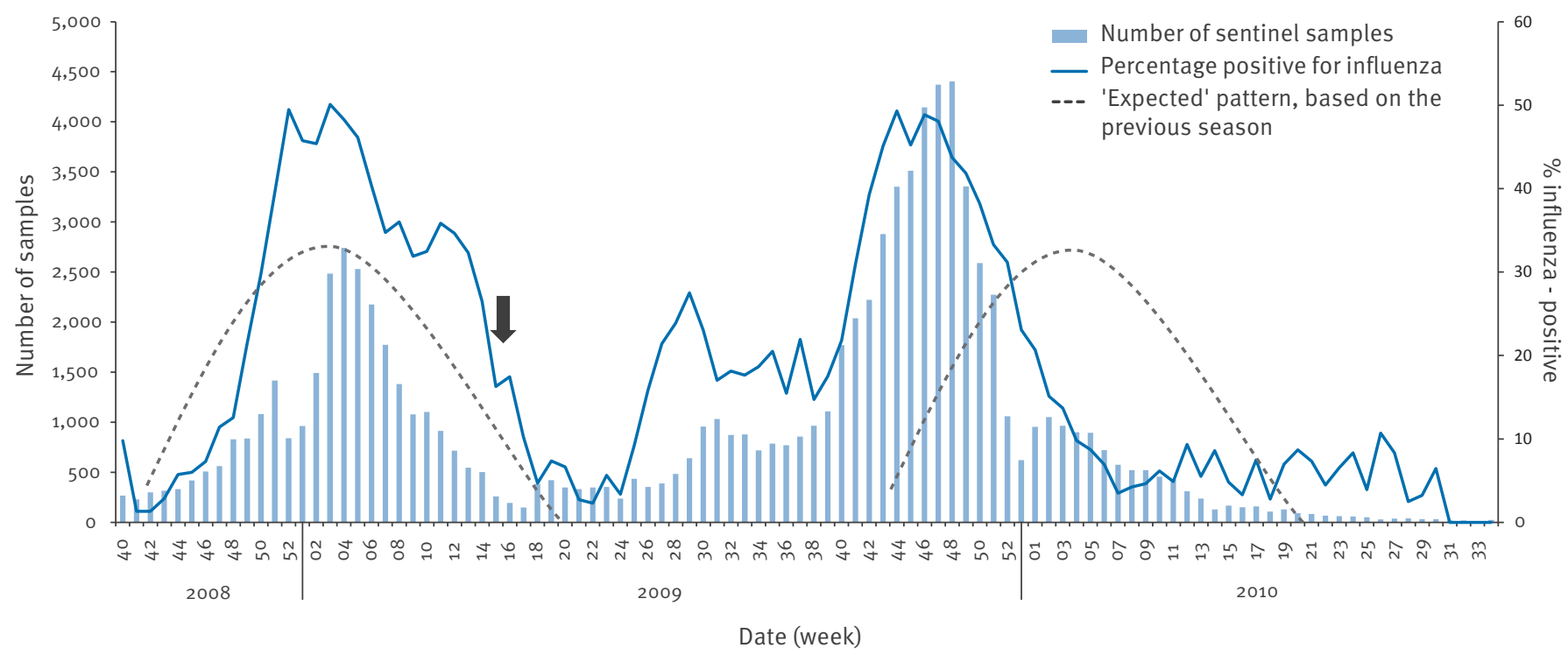

EU+2: the 27 European Union (EU) Member States plus Norway and Iceland.

The arrow denotes the probable start of the pandemic in Europe.

Source: European Influenza Surveillance Network (EISN) reports.

Data reported by 28 of 27 plus 2 countries. 


\section{FIGURE 3}

Distribution of virus types and subtypes detected from sentinel samples, seasons 2008/09 and 2009/10 in 28 EU+2 countries

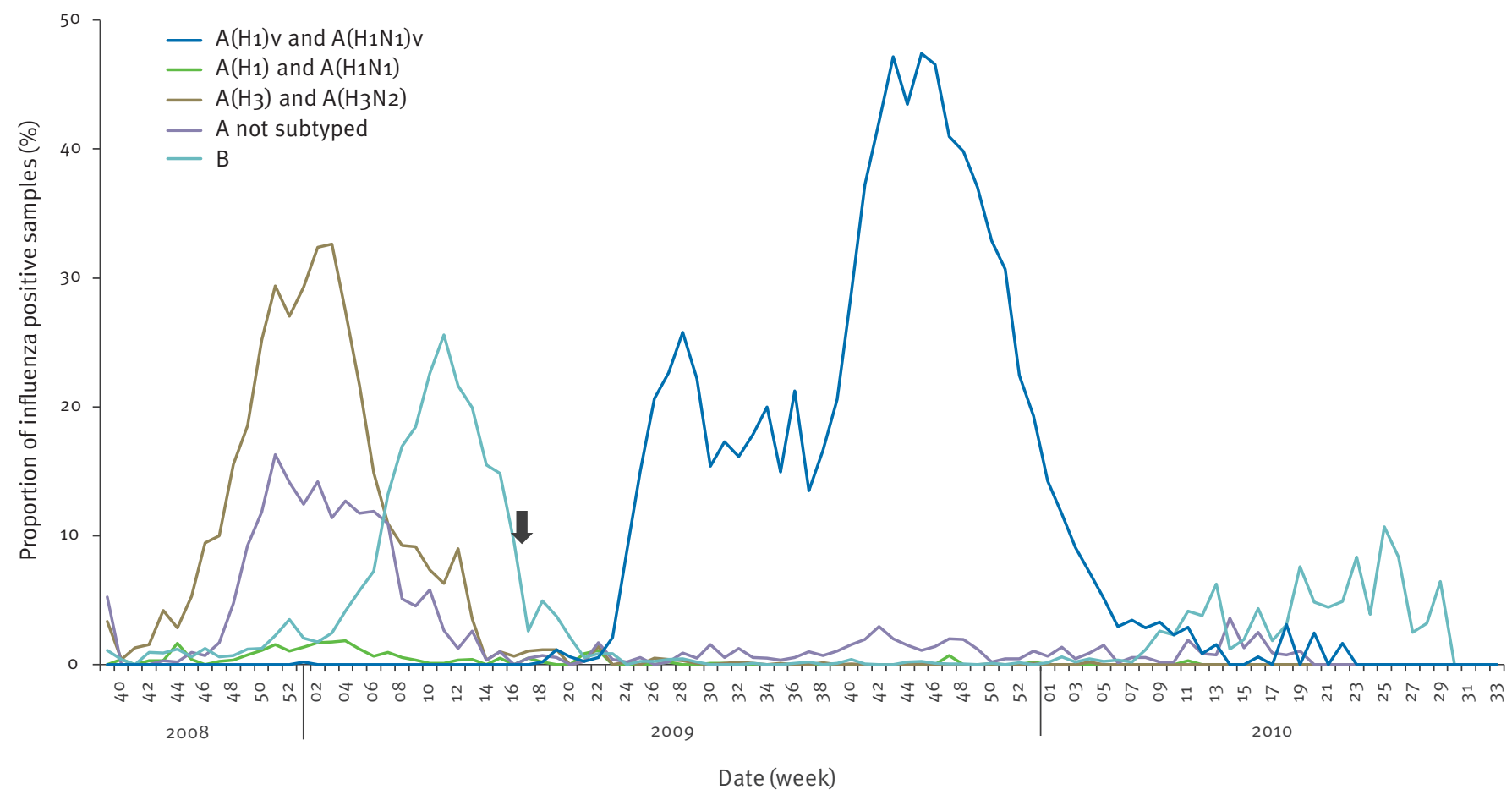

EU+2: the 27 European Union (EU) Member States plus Norway and Iceland.

The arrow denotes the probable start of the pandemic in Europe.

Source: European Influenza Surveillance Network (EISN) reports.

\section{FIGURE 4}

Officially announced and reported deaths due to pandemic influenza A(H1N1)2009 in the EU+2, by week of report, season $2009 / 10$

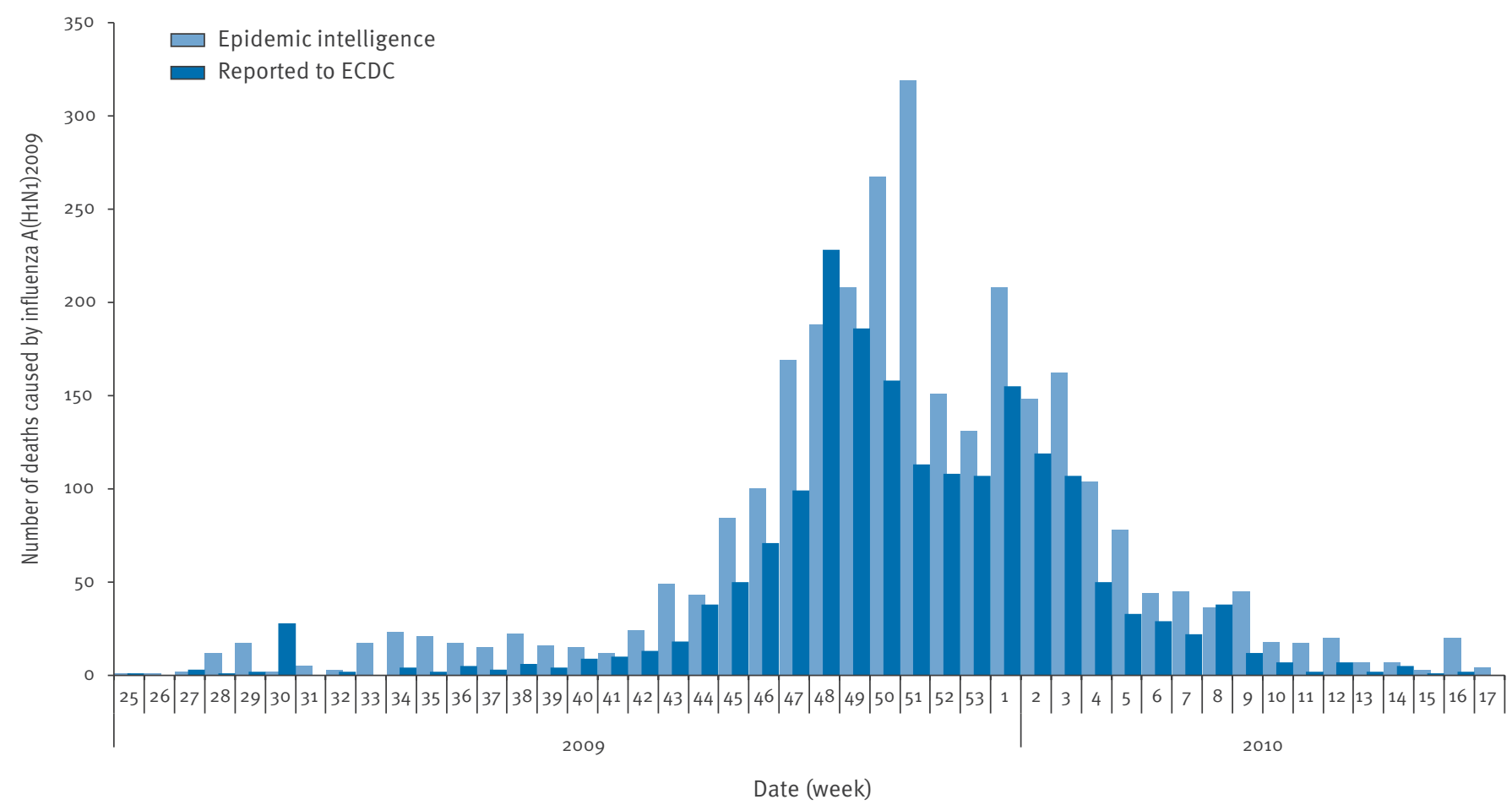

ECDC: European Centre for Disease Prevention and Control; EU+2: the 27 European Union (EU) Member States plus Norway and Iceland. Source: European Influenza Surveillance Network (EISN) reports and ECDC epidemic intelligence data collected from official national websites. 
general population as the network data are collected from sentinel sites and not representative of the general population. Overall rates for the EU/EEA cannot be estimated due to the different denominators used in the different countries.

The sentinel ILI and ARI networks also provide data on a limited number of age groups, but not on sex. All countries showed a consistent age distribution with children under the age of 14 years affected most. The ratio of the four age groups (under 4 years, 5-14 years, 15-64 years and over 65 years) was: 8:5:2:1.

These figures represent only a small proportion of the true attack rate, i.e. those who felt unwell enough to attend a primary care practice that happened to be part of the sentinel reporting system for that country [16], and should only be used to compare with the figures and proportions of similar data collected in a normal influenza season. The proportion of those experiencing illness or infection differed considerably from what was seen outside the pandemic [17] and this is described in more detail elsewhere [1].

There was considerable geographic heterogeneity in the amount of transmission, within Europe and even within countries, especially in the spring/summer wave. While there was transmission in most countries, only Spain and the UK recorded a prevalence of infection high enough to produce substantial numbers of severely affected people [11-13]. Overall attack rates estimated by serology were higher than for seasonal influenza, although the pandemic virus affected fewer older persons (65 years and older), who had been exposed to a similar virus circulating in the $1950 \mathrm{~s}$ and before $[16,18]$. There is clear evidence that there were many mild or asymptomatic cases in this pandemic, but whether they were more common than in the previously recorded pandemics is impossible to determine because it is only in this pandemic that there has been enough accurate seroepidemiology which combined with case reporting allowed such estimates to be made $[7,12,17]$. Attack rates were highest in young people, with country reports revealing that the highest rates of infection occurred in school-age children $[16,18]$ and some hospital paediatric services and intensive care services were especially stressed [19]. There was also pressure on primary care services in some areas because attack rates exceeded what was normally seen with seasonal influenza. No countries reported any pressure on critical services outside the healthcare sector, which is consistent with the WHO description of the pandemic: this pandemic, at least in its early days, will be of moderate severity (statement to the press by WHO Director-General Dr Margaret Chan, 11 June 2009)

\section{Virological surveillance}

The pandemic influenza $A\left(\mathrm{H}_{1} \mathrm{~N}_{1}\right) 2009$ virus displaced the previously dominant seasonal influenza $A$ virus strains in Europe, although late in both seasons 2008/09 and 2009/10, influenza B viruses were still prevalent enough to cause significant disease (Figures 2 and 3). From week 21, 2009 to week 16, 2010, 60,827 clinical samples were submitted by the sentinel practices reporting to the EISN, of which 25,304 (41.6\%) tested positive for influenza virus, almost all for the 2009 pandemic virus.

All pandemic influenza $A\left(\mathrm{H}_{1} \mathrm{~N}_{1}\right) 2009$ viruses isolated from samples submitted by the EISN sentinel practices for testing, were found to be resistant to antiviral drugs in the adamantane class, but very few of these samples $(2.5 \%)$ were found to be resistant to oseltamivir (Table 2). All oseltamivir-resistant strains were accounted for by the presence of the $\mathrm{H} 275 \mathrm{Y}$ mutation. Most of these mutations were observed following treatment of immunocompromised patients, and in Europe, resistant virus was only rarely transmitted

\section{TABLE 2}

Antiviral resistance by influenza virus type and subtype in samples collected by primary care sentinel networks in the EU+2, week 40, 2008-week 18, $2010(\mathrm{n}=1,454)$

\begin{tabular}{|c|c|c|c|c|c|c|c|c|c|c|c|c|}
\hline \multirow{4}{*}{$\begin{array}{l}\text { Influenza } \\
\text { virus } \\
\text { type and } \\
\text { subtype }\end{array}$} & \multicolumn{8}{|c|}{ Resistance to neuraminidase inhibitors } & \multicolumn{4}{|c|}{ Resistance to $\mathrm{M}_{2}$ inhibitors } \\
\hline & \multicolumn{4}{|c|}{ Oseltamivir } & \multicolumn{4}{|c|}{ Zanamivir } & \multirow{2}{*}{$\begin{array}{l}\text { Isolates } \\
\text { tested }\end{array}$} & \multirow{2}{*}{$\begin{array}{c}\text { Resistant } \\
\mathrm{n}(\%)\end{array}$} & \multirow{2}{*}{$\begin{array}{l}\text { Isolates } \\
\text { tested }\end{array}$} & \multirow[b]{2}{*}{$\begin{array}{c}\text { Resistant } \\
\mathrm{n}(\%)\end{array}$} \\
\hline & $\begin{array}{l}\text { Isolates } \\
\text { tested }\end{array}$ & $\begin{array}{c}\text { Resistant } \\
\mathrm{n}(\%)\end{array}$ & $\begin{array}{l}\text { Isolates } \\
\text { tested }\end{array}$ & $\begin{array}{l}\text { Resistant } \\
\mathrm{n}(\%)\end{array}$ & $\begin{array}{l}\text { Isolates } \\
\text { tested }\end{array}$ & $\begin{array}{c}\text { Resistant } \\
\mathrm{n}(\%)\end{array}$ & $\begin{array}{l}\text { Isolates } \\
\text { tested }\end{array}$ & $\begin{array}{l}\text { Resistant } \\
\mathrm{n}(\%)\end{array}$ & & & & \\
\hline & \multicolumn{2}{|c|}{$\begin{array}{l}\text { Week 40, 2008- } \\
\text { week 39, } 2009\end{array}$} & \multicolumn{2}{|c|}{$\begin{array}{c}\text { Week 40, 2009- } \\
\text { week 18, } 2010\end{array}$} & \multicolumn{2}{|c|}{$\begin{array}{c}\text { Week 40, 2008- } \\
\text { week 39, } 2009\end{array}$} & \multicolumn{2}{|c|}{$\begin{array}{c}\text { Week 40, 2009- } \\
\text { week } 18,2010\end{array}$} & \multicolumn{2}{|c|}{$\begin{array}{c}\text { Week 40, 2008- } \\
\text { week 39, } 2009\end{array}$} & \multicolumn{2}{|c|}{$\begin{array}{l}\text { Week } 40,2009- \\
\text { week } 18,2010\end{array}$} \\
\hline $\mathrm{A}\left(\mathrm{H}_{3} \mathrm{~N}_{2}\right)$ & 653 & o & 0 & 0 & 612 & 0 & 0 & 0 & 644 & $\begin{array}{c}644 \\
(100)\end{array}$ & 0 & 0 \\
\hline $\mathrm{A}\left(\mathrm{H}_{1} \mathrm{~N}_{1}\right)$ & 260 & $256(98)$ & 0 & 0 & 260 & o & 0 & 0 & 124 & $1(1)$ & 0 & 0 \\
\hline $\mathrm{A}\left(\mathrm{H}_{1} \mathrm{~N}_{1}\right) \mathrm{v}$ & 424 & 0 & 1,453 & $37(2.5 \%)$ & 415 & 0 & 1,447 & 0 & 56 & $56(100)$ & 205 & $205(100 \%)$ \\
\hline B & 117 & 0 & 0 & 0 & 113 & o & 0 & 0 & NA & NA & NA & NA \\
\hline
\end{tabular}

EU+2: the 27 European Union (EU) Member States plus Norway and Iceland; NA: not applicable, as M2 inhibitors do not act against influenza B viruses.

Source: European Influenza Surveillance Network (EISN) and Influenza Community Network of Reference Laboratories (CNRL) data in the European Centre for Disease Prevention and Control (ECDC)/European Surveillance System (TESSy). 
from one human to another unlike the seasonal influenza $A\left(\mathrm{H}_{1} \mathrm{~N}_{1}\right)$ virus with the same mutation, which is readily transmitted [20]. Although the viruses circulating during the pandemic were not identical, there is little evidence of significant drift or the emergence of dominant new variants to date [21]. A previously observed influenza $A\left(\mathrm{H}_{1} \mathrm{~N}_{1}\right)_{20} 00$ variant with a $\mathrm{D}_{222 \mathrm{G}}$ mutation has been associated with more severe disease, but it is still unclear whether this is due to a higher pathogenicity or a tropism for cells in the lower respiratory tract [21].

\section{Mortality, severe disease and risk groups}

In total, 2,900 pandemic deaths were announced by Member States in the first 12 months (Figure 4). This is probably only a proportion of the true burden of deaths due to the pandemic, but it remains unclear what that proportion is for Europe overall or for individual countries $[22,23]$. Pooling data from eight pilot countries, the EU-funded project European Monitoring of Excess Mortality for Public Health Action (EuroMOMO) detected excess all-cause mortality only in the 5-14 year-olds in the period between weeks 27 and 51 of 2009, compared with mortality in the previous three years. This estimate is probably conservative due to delays in reporting [24].

Before the autumn/winter wave of the pandemic, the EISN attempted to establish hospital-based sentinel surveillance of severe acute respiratory infection (SARI) cases, although this met with limited success [25]. During the autumn/winter wave, i.e. from week 36,2009 to week 20, 2010, 11,904 SARI cases and 586 SARI-related fatalities were reported to ECDC by eleven EU countries (Austria, Belgium, Cyprus, Finland, France, Ireland, Malta, the Netherlands, Romania, Slovakia and the United Kingdom, France only reported pandemic influenza $A\left(\mathrm{H}_{1} \mathrm{~N}_{1}\right) 2009$ cases admitted to intensive care units) [1]. Information on those with severe disease can be ascertained partially from this data and also from focused studies in EU Member States [13,26].

Building on these findings, the EU Health Security Committee defined pregnant women, those over six months of age with chronic ill health and healthcare workers as the primary risk groups that should be offered immunisation against pandemic influenza $[27,28]$

\section{Differences between the pandemic and seasonal influenza}

The pandemic differed from the preceding influenza season in a number of ways (Table 3 ). Most notable was the difference in the age of those most severely affected. Previously, were concentrated persons aged 65 years and older accounted for $90 \%$ of deaths from seasonal influenza [29,30]. In the 2009 pandemic, nearly $80 \%$ of the deaths reported to ECDC occurred in persons under 65 years [25], probably because a sizable proportion of older adults were protected by prior exposure to a similar influenza virus that had been circulating before the mid-1950s $[16,18]$. However, not all those older than 64 years were immune, and those without immunity who were infected had the highest case fatality rate of all age groups $[25,31]$. While the majority of deaths occurred in persons with chronic medical conditions, especially respiratory and neurological conditions, between $20 \%$ and $30 \%$ of the deaths reported in studies occurred in previously healthy individuals [31]. A considerable proportion of deaths were caused by acute respiratory distress syndrome (ARDS, mortality rate in 612 ARDS patients: $24.5 \%$ [25]), an extremely rare condition that is difficult to treat and that requires high dependency support for several weeks $[32,33]$ One of the reasons may have been that the new virus has shown a tropism for receptors found in the alveolar epithelium of the lungs [33].

\section{Serological data}

To date, there has been only limited data from serological surveys. These support the surveillance data indicating high infection rates, but they also suggest higher than expected levels of asymptomatic infection $[16,39]$. While the serological findings do not allow reliable predictions for the influenza season 2010/11, the experience of the temperate countries in the southern hemisphere during the European summer period of 2010 would probably provide some valuable clues.

\section{Conclusions}

The pandemic influenza $A\left(\mathrm{H}_{1} \mathrm{~N}_{1}\right) 2009$ virus started circulating in Europe around week 16 of 2009 (although the declared phase 5 only in week 18). It progressed into an initial spring/summer wave of transmission which occurred in most countries, but was striking only in a few, notably the UK. As the summer advanced, transmission briefly subsided, but then escalated again in the early autumn, just after the re-opening of the schools, this time affecting all countries. This autumn/winter wave was seen to progress from west to east across the continent. In most countries, this second wave of infection was brief but intense, lasting about 14 weeks, and was accompanied by a similar but slightly delayed wave of hospitalisations and deaths. By the time the WHO declared the pandemic officially over in August 2010 (week 32, 2010), the EU+2 had experienced transmission at a very low level for about 34 weeks.

An excess of all-cause deaths in school-age children was observed. Even though this was an influenza virus never seen previously, prior exposure to an antigenically similar influenza virus circulating before the mid 1950 s meant that many older people in Europe exhibited some immunity. Although many older people appeared to be protected, persons over the age of 65 years still had the highest case fatality rate of any age group.

The pandemic virus displaced the previously dominant seasonal influenza A viruses in Europe, although influenza $B$ viruses continued to appear at a low level late in the seasons. Few pandemic viruses were resistant 
to oseltamivir, and of these, very few seemed capable of human-to-human transmission. Although the pandemic viruses are not identical, there is little evidence of significant drift or the emergence of dominant new variants to date. One variant, influenza $A\left(\mathrm{H}_{1} \mathrm{~N}_{1}\right)_{2009}$ D222G has been associated with more severe disease, but a causative relationship has yet to be established.

Serological data suggest that there were a higher proportion of mild and asymptomatic infections than in the preceding influenza seasons. Nevertheless, transmission rates were higher than for seasonal infection and there were sufficient amounts of severe disease and notably cases of ARDS, which put a strain on intensive care services in many places. Young children (under five years of age) experienced the highest rates of disease, while country reports and serology indicate that the highest rates of infection (including asymptomatic) were in children at school age. These high rates of illness presented a particular burden for primary services, hospital paediatric services and especially intensive care in some areas.

Pandemic planning will now need to be revisited as the occurrence of this pandemic does not exclude the possibility of an influenza $\mathrm{A}\left(\mathrm{H}_{5}\right)$ or $\left(\mathrm{H}_{7}\right)$ pandemic emerging in the future. The next generation of plans need to include more flexibility for reacting to different severity of disease and different combinations of epidemiological parameters. In this context it would be useful to reach

\section{TABLE 3}

Comparing influenza seasons 2000/01-2008/09 with 2009 pandemic influenza

\begin{tabular}{|c|c|c|}
\hline & Seasonal influenza 2000/01-2008/09 & 2009 pandemic influenza \\
\hline $\begin{array}{l}\text { Circulating } \\
\text { influenza viruses }\end{array}$ & $\begin{array}{l}\text { Two influenza A viruses: } A\left(\mathrm{H}_{1} \mathrm{~N}_{1}\right) \text { and } \mathrm{A}\left(\mathrm{H}_{3} \mathrm{~N}_{2}\right) \text {, } \\
\text { and some influenza B viruses; the mix varies } \\
\text { with the season }\end{array}$ & $\begin{array}{l}\text { Almost exclusively the pandemic influenza } A\left(\mathrm{H}_{1} \mathrm{~N}_{1}\right) 2009 \text {, a few } \\
\text { influenza } A\left(\mathrm{H}_{3} \mathrm{~N}_{2}\right) \text { viruses and increasing numbers of influenza } B \\
\text { viruses towards the end of the season }\end{array}$ \\
\hline $\begin{array}{l}\text { When waves } \\
\text { occurred }\end{array}$ & $\begin{array}{l}\text { In season, in recent years most often starting } \\
\text { after Christmas }\end{array}$ & $\begin{array}{l}\text { Started out of season with a spring/summer wave, then an early } \\
\text { autumn/winter wave in Europe }\end{array}$ \\
\hline $\begin{array}{l}\text { Levels of } \\
\text { transmission }\end{array}$ & $\begin{array}{l}\text { Variable from year to year, with local } \\
\text { heterogeneity, but estimated to be } 5-15 \% \\
\text { annually }\end{array}$ & $\begin{array}{l}\text { Hard to estimate, local heterogeneity, estimated to be over } 15 \% \\
\text { through serological studies in New Zealand [34] and in the United } \\
\text { Kingdom [16] }\end{array}$ \\
\hline $\begin{array}{l}\text { Setting for } \\
\text { transmission }\end{array}$ & $\begin{array}{l}\text { Probably any setting where people come } \\
\text { together }\end{array}$ & $\begin{array}{l}\text { Schools considered especially important, along with household } \\
\text { transmission }\end{array}$ \\
\hline $\begin{array}{l}\text { Experiencing } \\
\text { severe disease }\end{array}$ & Those in clinical risk groups and older people & $\begin{array}{l}\text { Young children, pregnant women and those in clinical risk groups; } \\
\text { about } 30 \% \text { with severe disease were outside risk groups; many } \\
\text { born before the mid-1950s were immune, but people in this } \\
\text { age group who were not immune experienced severe disease } \\
\text { outcomes [31] }\end{array}$ \\
\hline Premature deaths & $\begin{array}{l}\text { Around } 90 \% \text { considered to have occurred in } \\
\text { people } 65 \text { years or older }\end{array}$ & $\begin{array}{l}\text { In confirmed reported deaths, around } 80 \% \text { were under } 65 \text { years } \\
\text { of age } \\
\text { Increase in all-cause deaths in children detected across eight EU } \\
\text { countries by EuroMOMO system[24] }\end{array}$ \\
\hline $\begin{array}{l}\text { Mortality and } \\
\text { years of potential } \\
\text { life lost }\end{array}$ & $\begin{array}{l}\text { Few confirmed deaths reported each year in } \\
\text { official statistics; estimates of up to } 40,000 \text { in a } \\
\text { bad year using statistical methods }\end{array}$ & $\begin{array}{l}\text { Substantial numbers of confirmed deaths announced by EU+2 } \\
\text { Member States ( } n=2,900 \text {, Figure } 4) \text { but recognised to be an } \\
\text { underestimate } \\
\text { Only estimated in one EU Member State (the Netherlands, } 35 \\
\text { disability-adjusted life years per 100,000 population) [35], but } \\
\text { estimated in the United States with considerably higher levels [36] }\end{array}$ \\
\hline $\begin{array}{l}\text { Acute respiratory } \\
\text { distress } \\
\text { syndrome }\end{array}$ & Extremely rare & $\begin{array}{l}\text { Uncommon, but recorded in many countries, even in young fit } \\
\text { adults; partially explained by the tropism of the pandemic virus } \\
\text { for epithelial receptors that predominate in the alveoli of the lung, } \\
\text { while the previous seasonal viruses bind best to receptors found } \\
\text { predominately in the upper airways [33] }\end{array}$ \\
\hline $\begin{array}{l}\text { Antiviral } \\
\text { resistance }\end{array}$ & $\begin{array}{l}\text { Common and transmissible oseltamivir } \\
\text { resistance in influenza } A\left(\mathrm{H}_{1} \mathrm{~N}_{1}\right) \text { emerged in } \\
\text { season } 2007 / 08[38]\end{array}$ & $\begin{array}{l}\text { Observed most often following antiviral treatment of susceptible } \\
\text { individuals; however, as of July } 2010 \text {, only transmitted very rarely } \\
\text { under certain circumstances [33]; resistant seasonal influenza } \\
A\left(\mathrm{H}_{1} \mathrm{~N}_{1}\right) \text { seemingly displaced by the new influenza, at least for now }\end{array}$ \\
\hline
\end{tabular}

ECDC: European Centre for Disease Prevention and Control; EU: European Union; EU+2: the 27 European Union (EU) Member States plus Norway and Iceland; EuroMOMO: project European Monitoring of Excess Mortality for Public Health Action; WHO: World Health Organization. This table lists ten characteristics in which the new pandemic influenza differs from the 'old' seasonal influenza, especially as they appeared in more recent years (seasons 2000/01-2008/09).

Source: http://ecdc.europa.eu/en/activities/sciadvice/Lists/ECDC\%20Reviews/ECDC_DispForm.aspx?List=512ff74f\%2D77d4\%2D4ad8\%2Db6d $6 \% 2$ Dbfof 23083 f30\&ID=911\&RootFolder $=\% 2$ Fen $\% 2$ Factivities $\% 2$ Fsciadvice $\% 2$ FLists $\% 2$ FECDC $\% 20$ Reviews 
a European consensus on describing and assessing the severity of a pandemic, and matching the response with the different scales and characteristics. These plans must also provide for the consolidation and sustainability of the influenza surveillance systems that were introduced to meet the demands of the 2009 pandemic, in particular SARI, attributable mortality, and seroepidemiological surveillance. This surveillance work needs to be prioritised, given the right level of resources and allowed to develop and be tested during the interpandemic period so that the systems will be more resilient and effective in a future public health crisis.

At an early stage, it was appreciated that this pandemic was much less severe than what many European countries had feared and prepared for. This was highlighted in the first ECDC Risk Assessments (available at: http:// ecdc.europa.eu/en/healthtopics/H1N1/risk_threat assessment/Pages/risk_threat_assessment.aspx), WHO reports and briefings given by ECDC to national and European authorities. With low rates of absenteeism, there was also little impact on services outside the health sector. In conclusion this pandemic was a mild one for Europe [40], testing the flexibility of existing preparedness plans in many countries. The greatest challenge during this pandemic was in the area of risk communication, as both the professionals and the general population expected something more severe [41].

The pandemic occurred at a time when diagnostic tests could be made available quickly, as well as preventive pharmaceutical countermeasures (antiviral drugs for a virus with little resistance to the neuraminidase inhibitors but almost complete resistance to the older adamantanes) and when appropriate vaccines were developed and made available faster than ever before. The occurrence of cases of ARDS when many intensive care units were already busy put particular pressure on the system without the ability to redeploy hospital staff internally, even though the rest of the hospitals were not that stressed [33]. The rapidly produced pandemic vaccines showed such a good immunological response that several formulations only required a single dose in adults [42]. They have also proved to be effective and relatively safe [42], although post-marketing surveillance still needs to be maintained to determine exactly how safe they are and to investigate initial signals of adverse events following immunisation (AEFIs) [43]. There were still delays in the production of vaccines, so that even countries with advance purchase agreements received too little vaccine too late to have any real impact at the population level. However, the high vaccine efficacy and targeting of risk groups may have saved lives of European citizens. Where vaccines were made available, they were greeted with varying degrees of enthusiasm among health professionals. That these vaccines were not widely accepted was partly due to the difficulty in transmitting the complex risk communication message. On the one hand the chance of severe disease following infection was very low unless the individual belonged to a risk group (young children, people with chronic ill health and pregnant women [33]). On the other hand, there was a small but real risk of severe disease and death from the pandemic in all healthy persons. The challenge of communicating this risk was considerable.

\section{Limitations of the EU+2 data}

The data used here were subject to limitations and the results should be interpreted with a degree of caution. The reported ILI or ARI surveillance data were not comparable between countries as there was variability in the data sources, size and representativeness of the networks. The ILI/ARI epidemic curves were also distorted because several countries, at different points in time, actively recommended that anyone with influenza-like symptoms should stay at home and not approach their primary care provider, (contrary to what the patients would do in a normal influenza season), thus excluding them being reported. In addition, there are indications from specialist studies that the usual patterns of seeking care were distorted during the pandemic and that this varied over time as the perception of risk changed [17].

The virological data are derived from samples sent for laboratory testing and confirmation. They represent only a selected subset of the cases, usually the more severely affected seeking medical help. The sentinel samples were representative of patients attending general practices, while the non-sentinel samples derive from a varying mix of general practitioners' diagnoses not included in the sentinel system and more seriously affected cases that were admitted to hospital. Therefore the non-sentinel data were a mixture of mild and severe cases, which can differ by country. One important aspect of laboratory- based surveillance that was missing at the European level was routine seroprevalence monitoring. Although a few countries carried out local studies that provided valuable information $[16,18,44,45]$, this work was not carried out in a standardised and comparable manner early on in the pandemic. Also, the results were made available too late to be of use and it was not clear if the information they provided could be extrapolated to other countries.

The systems for collecting data on the more severe cases (SARI) or deaths were introduced in response to the pandemic, after the pandemic had already reached Europe. This is not the optimal time to introduce a new system, as the countries' surveillance systems had to adapt or introduce new processes at a time when their resources were already stretched. There seem to be difficulties in capturing data on SARI cases in many European hospitals because it is not a diagnosis recognised by clinicians as it encompasses young children with bronchiolitis, older people with pneumonia and ARDS. Some countries found it easier to collect data on people hospitalised with an influenza diagnosis. Also, there was variability in what different sites reported as SARI as well as in providing reliable estimates of the denominators and the representativeness of the data, shedding doubt on the estimated rates. 
Not only reported cases were underestimated, but also deaths due to the 2009 pandemic influenza, especially in the elderly where influenza is known to be frequently masked by other conditions as the underlying cause of death [46]. Presently, only ad hoc studies can attempt to estimate influenza-related mortality more accurately, and while such studies have been done in the United States [47], there have not been any in Europe

\section{New characteristics of the 2009 \\ influenza pandemic}

Nevertheless, the EU/EEA surveillance data permit us to conclude on a number of new characteristics of this pandemic (Box), notably the reliance on clinicians to deliver the most powerful countermeasures. Much prominence was given to the doubts expressed by the professionals in some countries on the value of the countermeasures. Moreover, the role of the media in this pandemic was unprecedented and this was not always positive, for example when vaccine opponents and pandemic skeptics were given the same platform as expert opinions.

\section{Lessons learnt for surveillance}

The fact that the 2009 influenza $A\left(\mathrm{H}_{1} \mathrm{~N}_{1}\right)$ pandemic was less of a threat than what many countries had prepared for, tested the flexibility of existing plans. Nevertheless no country appears to have over-responded, while the systems developed by the European Commission, WHO and ECDC for discussing and sharing information and analyses proved resilient and useful. On balance, the $\mathrm{EU}+2$ managed the response to the pandemic well [49], although this can be further improved. The EISN virological and primary care-based surveillance in particular worked well, and served to augment the data emerging from the ECDC epidemic intelligence and targeted science watch sources. Establishing surveillance in hospitals and sharing analyses from the first affected countries were

\section{Box}

New characteristics about the 2009 pandemic in Europe

- The first pandemic with instant communication so that early impressions (such as the experience in Mexico and the Ukraine) were transmitted ahead of any reasonable or thoughtful analysis;

- The first pandemic that took place within the context of a set of International Health Regulations [48] and global governance, although essentially untried;

- The first pandemic with early diagnostic tests which led to rapid diagnosis but also an early overly strong focus by the media and policymakers on the numbers of infected people;

- The first pandemic with antiviral drugs available which led to an expectation that the pandemic might be containable and the invention of a containment phase by some countries

- The first pandemic in which effective countermeasures (antiviral drugs and vaccines) could be provided by clinicians, which meant the confidence of those doctors and nurses had to be earned and retained;

- The first pandemic in a setting with effective intensive care and thus with a (false) expectation that everyone could be treated and cured;

- The first pandemic which received uncontrolled coverage in blogs that policy makers needed to monitor closely. less successful. It was fortunate that data and analyses were quickly available from North America and the southern hemisphere. Lessons to be learnt include:

- Routine 'severe end' surveillance of hospitalised cases and deaths due to severe respiratory infection should be established in Europe.

- In the future, the process for sharing early analyses from the first affected countries can work better, possibly by increasing the faith of expert colleagues in the confidentiality and security of certain communication systems and the discretion of other experts in the country not to pass on provisional data.

- Much work, including research and development, needs to take place to make seroepidemiology available in real time.

The members of the European Influenza Surveillance Network (EISN) are:

Gabriela El Belazi, Hubert Hrabcik, Peter Lachner, Reinhild Strauss, Robert Muchl, Theresia Popow - Kraupp, Monika Redlberger-Fritz, Françoise Wuillaume, Françoise Wuillaume, Viviane Van Casteren, Isabelle Thomas, Bernard Brochier, Mira Kojouharova, Rositsa Kotseva, Teodora Georgieva, Avraam Elia, Chryso Gregoriadou, Chrystalla Hadjianastassiou, Despo Pieridou Bagatzouni, Olga Kalakouta, Jan Kyncl, Martina Havlickova, Andreas Gilsdorf, Brunhilde Schweiger, Gabriele Poggensee, Gerard Krause, Silke Buda, Tim Eckmanns, Anne Mazick, Annette Hartvig Christiansen, Kåre Mølbak, Lars Nielsen, Steffen Glismann, Inna Sarv, Irina Dontsenko, Jelena Hololejenko, Natalja Njunkova, Natalia Kerbo, Olga Sadikova, Tiiu Aro, Amparo Larrauri, Gloria Hernandez - Pezzi, Pilar Perez Brena, Rosa Cano - Portero, Markku Kuusi, Petri Ruutu, Thedi Ziegler, Sophie Vaux, Isabelle Bonmarin, Daniel Lévy-Bruhl, Bruno Lina, Martine Valette, Sylvie Van Der Werf, Vincent Enouf, Ian Fisher, John Watson, Joy Kean, Maria Zambon, Mike Catchpole, Peter Coyle, William F Carman, Stefanos Bonovas, Takis Panagiotopoulos, Sotirios Tsiodras, Ágnes Csohán, Istvan Jankovics, Katalin Kaszas, Márta Melles, Monika Rozsa, Zsuzsanna Molnár, Darina O'flanagan, Derval Igoe, Joan O'donnell, John Brazil, Margaret Fitzgerald, Peter Hanrahan, Sarah Jackson, Suzie Coughlan, Jeff Connell, Margaret Duffy, Joanne Moran, Professor William Hall, Arthur Löve, Gudrun Sigmundsdottir, Simona Puzelli, Isabella Donatelli, Maria Grazia Pompa, Stefania D’amato, Stefania Iannazzo, Annapina Palmieri, Sabine Erne, Algirdas Griskevicius, Nerija Kupreviciene, Rasa Liausediene, Danielle Hansen - Koenig, Joel Mossong, Mathias Opp, Claude P. Muller, Jacques Kremer, Patrick Hau, Pierre Weicherding, Antra Bormane, Irina Lucenko, Natalija Zamjatina, Raina Nikiforova, Charmaine Gauci, Christopher Barbara, Gianfranco Spiteri, Tanya Melillo, Marianne van der Sande, Adam Meijer, Frederika Dijkstra, Gé Donker, Guus Rimmelzwaan,, Simone Van Der Plas,Wim Van Der Hoek, Katerine Borgen, Susanne Dudman, Siri Helene Hauge, Olav Hungnes, Anette Kilander, Preben Aavitsland, Andrzej Zielinski, Lidia Brydak, Magdalena Romanowska, Malgorzata Sadkowska - Todys, Maria Sulik, Carlos Manuel Orta Gomes, Jose Marinho Falcao, Raquel Guiomar, Teresa Maria Alves Fernandes, Adriana Pistol, Emilia Lupulescu, Florin Popovici, Viorel Alexandrescu, Annika Linde, Asa Wiman, Helena Dahl, Malin Arneborn, Mia Brytting, Katarina Prosenc, Maja Socan, Katarina Prosenc, Maja Socan, Hana Blaskovicova, Margareta Slacikova, Mária Avdicová, Martina Molcanová, Šárka Kovácsová. 


\section{References}

1. European Centre for Disease Prevention and Control (ECDC). The $2009 \mathrm{~A}\left(\mathrm{H}_{1} \mathrm{~N}_{1}\right)$ pandemic in Europe. Stockholm: ECDC; 2010. Available from: http://ecdc.europa.eu/en/publications/ Publications/101108_SPR_pandemic_experience.pdf

2. European Centre for Disease Prevention and Control (ECDC). Meeting report. Annual meeting of the European Influenza Surveillance Network. Sofia, 1-3 June 2010. Stockholm: ECDC 2011. Available from: http://ecdc.europa.eu/en/publications/ Publications/1101_MER_EISN_2010.pdf

3. European Centre for Disease Prevention and Control (ECDC). Technical document. Overview of surveillance of influenza 2009/2010 in the EU/EEA. Stockholm: ECDC; 2009. Available from: http://ecdc.europa.eu/en/publications/ Publications/0909_TED_Overview_of_Surveillance_of_ Influenza_2009-2010_in_EU-EEA.pdf

4. European Centre for Disease Prevention and Control (ECDC). Meeting report. Surveillance and studies in a pandemic: Fourth meeting of the SSiaP working group. Stockholm, July 2009. Stockholm: ECDC; 2009. Available from: http://ecdc.europa. eu/en/publications/Publications/0908 MER Surveillance and_Studies_in_a_Pandemic_Meeting_Report.pdf

5. Kaiser R, Coulombier D. Different approaches to gathering epidemic intelligence in Europe. Euro Surveill. 2006;11(17): pii=2948. Available from: http://www. eurosurveillance.org/ViewArticle.aspx?PublicationType $=W \& V o l$ ume $=11 \&$ Issue $=17 \&$ OrderNumber $=1$

6. Centers for Disease Control and Prevention (CDC).Outbreak of swine-origin influenza $A\left(\mathrm{H}_{1} \mathrm{~N}_{1}\right)$ virus infection - Mexico, MarchApril 2009. MMWR Morb Mortal Wkly Rep. 2009;58(17):467-70.

7. Devaux I, Kreidl P, Penttinen P, Salminen M, Zucs P, Ammon A; et al. Initial surveillance of 2009 influenza $A\left(\mathrm{H}_{1} \mathrm{~N}_{1}\right)$ pandemic in the European Union and European Economic Area, AprilSeptember 2009. Euro Surveill. 2010;15(49):pii=19740. Available from: http://www.eurosurveillance.org/ViewArticle. aspx?Articleld $=19740$.

8. European Centre for Disease Prevention and Control (ECDC). ECDC interim risk assessment. Human cases of influenza $A\left(\mathrm{H}_{1} \mathrm{~N}_{1}\right)$ v. 12 June 2009. Stockholm: ECDC; 2009. Available from: http://www.ecdc.europa.eu/en/healthtopics/H1N1/ Documents/1001_RA_090612.pdf

9. Transmission dynamics and impact of pandemic influenza $A$ $\left(\mathrm{H}_{1} \mathrm{~N}_{1}\right) 2009$ virus. Wkly Epidemiol Rec. 2009;84(46):481-4.

10. White LF, Wallinga J, Finelli L, Reed C, Riley S, Lipsitch M, et al. Estimation of the reproductive number and the serial interval in early phase of the 2009 influenza $\mathrm{A} / \mathrm{H}_{1} \mathrm{~N}_{1}$ pandemic in the USA. Influenza Other Respi Viruses. 2009;3(6):267-76.

11. Health Protection Agency (HPA). The role of the Health Protection Agency in the 'containment' phase during the first wave of pandemic influenza in England in 2009. London: HPA; March 2010. Available from: http://www.hpa.org.uk/web/ HPAwebFile/HPAweb_C/1274088320581

12. Health Protection Agency (HPA). Pandemic ( $\left.\mathrm{H}_{1} \mathrm{~N}_{1}\right) 2009$ in England: an overview of initial epidemiological findings and implications for the second wave. v4. 2 December 2009. London: HPA. Available from: http://www.hpa.org.uk/web/ HPAwebFile/HPAweb_C/1258560552857

13. Santa-Olalla Peralta $P$, Cortes-García M, Vicente-Herrero $M$, Castrillo-Villamandos C, Arias-Bohigas P, Pachon-del Amo I, et al. Risk factors for disease severity among hospitalised patients with 2009 pandemic influenza A ( $\left.\mathrm{H}_{1} \mathrm{~N}_{1}\right)$ in Spain, April - December 2009. Euro Surveill. 2010;15(38):pii=19667. Available from: http://www.eurosurveillance.org/ViewArticle. aspx?Articleld=19667. 2010.

14. Health Protection Agency West Midlands $\mathrm{H}_{1} \mathrm{~N}_{1}$ v Investigation Team. Preliminary descriptive epidemiology of a large school outbreak of influenza $A\left(\mathrm{H}_{1} \mathrm{~N}_{1}\right) \mathrm{v}$ in the West Midlands, United Kingdom, May 2009. Euro Surveill. 2009;14(27):pii=19264. Available from: http://www.eurosurveillance.org/ViewArticle. aspx?Articleld $=19264$

15. European Centre for Disease Prevention and Control (ECDC), ECDC forward look risk assessment. Likely scenarios for influenza in 2010 and the 2010/2011 influenza season in Europe and the consequent work priorities. Stockholm: ECDC; March 2010. Available from: http://www.bepast.org/docs/ global\%2obiodefense/2010-3-9_RA_forward_look_influenza ECDC.pdf

16. Miller E, Hoschler K, Hardelid P, Stanford E, Andrews N, Zambon M. Incidence of 2009 pandemic influenza $\mathrm{A} \mathrm{H}_{1} \mathrm{~N}_{1}$ infection in England: a cross-sectional serological study. Lancet. 2010;375(9720):1100-8.
17. Lim MSC, Bermingham A, Edmunds J, Fragaszy E, Harvey G, Johnson A, et al. Flu watch - community burden of influenza during three inter-pandemic influenza seasons and the summer wave of the $2009 \mathrm{H}_{1} \mathrm{~N}_{1}$ pandemic in England - implications for interpretation of surveillance data. Presented at the Options for the Control of Influenza VII. Hong Kong SAR, China, 3-7 September 2010.

18. Hardelid P, Andrews NJ, Hoschler K, Stanford E, Baguelin M, Waight PA, et al. Assessment of baseline age-specific antibody prevalence and incidence of infection to novel influenza A/ H1N1 2009. Health Technol Assess. 2010;14(55):115-92.

19. Kilander A, Rykkvin R, Dudman SG, Hungnes O. Observed association between the HA1 mutation $\mathrm{D}_{222} \mathrm{G}$ in the 2009 pandemic influenza $A\left(\mathrm{H}_{1} \mathrm{~N}_{1}\right)$ virus and severe clinical outcome, Norway 2009-2010. Euro Surveill. 2010;15(9):pii=19498. Available from: http://www.eurosurveillance.org/ViewArticle. aspx?Articleld $=19498$

20. Meijer A, Lackenby A, Hay A, Zambon M. Influenza antiviral susceptibility monitoring activities in relation to national antiviral stockpiles in Europe during the winter 2006/2007 season. Euro Surveill. 2007;12(4):pii=698. Available from: http://www.eurosurveillance.org/ViewArticle. aspx?Articleld $=698$

21. Preliminary review of $\mathrm{D} 222 \mathrm{G}$ amino acid substitution in the haemagglutinin of pandemic influenza $A\left(\mathrm{H}_{1} \mathrm{~N}_{1}\right) 2009$ viruses. Wkly epidemiol rec. 2010;85(4):21-2.

22. Gran JM, Iversen B, Hungnes O, Aalen 00. Estimating influenza-related excess mortality and reproduction numbers for seasonal influenza in Norway, 1975-2004. Epidemiol Infect. 2010;138(11):1559-68

23. Pebody RG, McLean E, Zhao H, Cleary P, Bracebridge S, Foster K, et al. Pandemic Influenza A (H1N1) 2009 and mortality in the United Kingdom: risk factors for death, April 2009 to March 2010. Euro Surveill. 2010;15(20):pii=19571. Available from: http://www.eurosurveillance.org/ViewArticle. aspx?Articleld $=19571$

24. Mazick A, Gergonne B, Wuillaume F, Danis K, Vantarakis A, Uphoff $\mathrm{H}$, et al. Higher all-cause mortality in children during autumn 2009 compared with the three previous years: pooled results from eight European countries. Euro Surveill. 2010;15(5):pii=19480. Available from: http://www. eurosurveillance.org/ViewArticle.aspx?Articleld=19480

25. Snacken R. Surveillance of severe ARI, experiences from the first season. Presentation at the annual meeting of the European Influenza Surveillance Network (EISN). Sofia, Bulgaria, 2 June 2010.

26. Nguyen-Van-Tam JS, Openshaw PJ, Hashim A, Gadd EM, Lim WS, Semple MG, et al. Risk factors for hospitalisation and poor outcome with pandemic $\mathrm{A} / \mathrm{H}_{1} \mathrm{~N}_{1}$ influenza: United Kingdom first wave (May-September 2009). Thorax. 2010;65(7):645-51.

27. Nokleby $\mathrm{H}$, Nicoll A. Risk groups and other target groups - preliminary ECDC guidance for developing influenza vaccination recommendations for the season 2010-11. Euro Surveill. 2010;15(12):pii=19525. Available from: http://www. eurosurveillance.org/ViewArticle.aspx?Articleld=19525

28. European Centre for Disease Prevention and Control (ECDC), ECDC interim guidance. Use of specific pandemic influenza vaccines during the $\mathrm{H}_{1} \mathrm{~N}_{1} 2009$ pandemic. August 2009. Stockholm: ECDC; 2009. Available from: http://ecdc.europa. eu/en/publications/Publications/0908 GUI Pandemic Influenza_Vaccines_during_the_H1N1_2009_Pandemic.pdf

29. Nicoll A, Ciancio BC, Tsolova S, Blank PR, Yilmaz C. The scientific basis for offering seasonal influenza immunisation to risk groups in Europe. Euro Surveill. 2008;13(43): pii=19018. Available from: http://www.eurosurveillance.org/ViewArticle. aspx?Articleld =19018

30. Thompson WW, Shay DK, Weintraub E, Brammer L, Bridges CB, Cox NJ, et al. Influenza-associated hospitalizations in the United States. JAMA. 2004;292(11):1333-40.

31. Donaldson LJ, Rutter PD, Ellis BM, Greaves FE, Mytton OT, Pebody RG, et al. Mortality from pandemic A/H1 $\mathrm{N}_{1} 2009$ influenza in England: public health surveillance study. BMJ. 2009;339:b5213.

32. Ware LB, Matthay MA. The acute respiratory distress syndrome. N Engl J Med. 2000;342(18):1334-49.

33. Writing Committee of the WHO Consultation on Clinical Aspects of Pandemic $\left(\mathrm{H}_{1} \mathrm{~N}_{1}\right) 2009$ Influenza, Bautista $\mathrm{E}$, Chotpitayasunondh T, Gao Z, Harper SA, Shaw Met al. Clinical aspects of pandemic 2009 influenza $A\left(\mathrm{H}_{1} \mathrm{~N}_{1}\right)$ virus Infection. $\mathrm{N}$ Engl J Med. 2010;362(18):1708-19.

34. Environmental Science and Research Limited (ESR). Seroprevalence of the 2009 influenza $A\left(\mathrm{H}_{1} \mathrm{~N}_{1}\right)$ pandemic in New Zealand. ESR; May 2010. Available from: http://www. moh.govt.nz/moh.nsf/pagesmh/10124/\$File/seroprevalenceflu-2009.pdf 
35. Wielders CC, van Lier EA, van 't Klooster TM, van GageldonkLafeber AB, van den Wijngaard CC, Haagsma JA, et al. The burden of 2009 pandemic influenza $A\left(\mathrm{H}_{1} \mathrm{~N}_{1}\right)$ in the Netherlands. Eur J Public Health. 2010 Dec 22. [Epub ahead of print].

36. Centers for Disease Control and Prevention (CDC). Updated CDC estimates of $2009 \mathrm{H}_{1} \mathrm{~N}_{1}$ influenza cases, hospitalizations and deaths in the United States, April 2009 - April 10, 2010. Atlanta: CDC. [Accessed 20 Jun 2010]. Available from: http:// www.cdc.gov/h1n1flu/estimates 2009 h1n1.htm

37. Shieh WJ, Blau DM, Denison AM, Deleon-Carnes M, Adem $P$, Bhatnagar J, et al. 2009 pandemic influenza $A\left(\mathrm{H}_{1} \mathrm{~N}_{1}\right)$ : pathology and pathogenesis of 100 fatal cases in the United States. Am J Pathol. 2010;177(1):166-75.

38. Meijer A, Lackenby A, Hungnes O, Lina B, van-der-Werf S, Schweiger B, et al. Oseltamivir-resistant influenza virus $A\left(\mathrm{H}_{1} \mathrm{~N}_{1}\right)$, Europe, 2007-08 season. Emerg Infect Dis. 2009;15(4):552-60.

39. Waalen K, Kilander A, Dudman SG, Krogh GH, Aune T, Hungnes O. High prevalence of antibodies to the 2009 pandemic influenza $A\left(\mathrm{H}_{1} \mathrm{~N}_{1}\right)$ virus in the Norwegian population following a major epidemic and a large vaccination campaign in autumn 2009. Euro Surveill. 2010;15(31):pii=19633. Available from: http://www.eurosurveillance.org/ViewArticle. aspx?Articleld $=19633$

40. Nicoll A, McKee M. Moderate pandemic, not many dead-learning the right lessons in Europe from the 2009 pandemic. Eur J Public Health. 2010;20(5):486-8

41. Abraham T. The price of poor pandemic communication. BMJ. 2010;340:C2952.

42. European Medicines Agency (EMA). European

Medicines Agency reaffirms efficacy and safety of $\mathrm{H}_{1} \mathrm{~N}_{1}$ pandemic vaccines. London: EMA; 20 November 2009. EMEA/748707/2009. Press Release. Available from: http:// www.ema.europa.eu/docs/en_GB/document_library/Press_ release/2009/11/WC500015558.pdf

43. Merecekiene_J. Overview of pandemic $A\left(\mathrm{H}_{1} \mathrm{~N}_{1}\right) 2009$ influenza vaccination in Europe. Preliminary results of survey conducted by VENICE, 2010. Presentation at ESCAIDE 2010, Lisbon, Portugal, 13 November 2010. Available from: http://ecdc. europa.eu/en/ESCAIDE/ESCAIDE\%20Presentations\%2olibrary/ ESCAIDE2010_Late_Breakers_Mereckiene.pdf

44. Ikonen N, Strengell M, Kinnunen L, Österlund P, Pirhonen J, Broman $M$, et al. High frequency of cross-reacting antibodies against 2009 pandemic influenza $A\left(\mathrm{H}_{1} \mathrm{~N}_{1}\right)$ virus among the elderly in Finland. Euro Surveill. 2010;15(5):pii=19478. Available from: http://www.eurosurveillance.org/ViewArticle. aspx?Articleld $=19478$

45. Seroepidemiological studies of pandemic influenza $A\left(\mathrm{H}_{1} \mathrm{~N}_{1}\right)$ 2009 virus. Wkly Epidemiol Rec. 2010;85(24):229-35.

46. World Health Organization (WHO). Comparing deaths from pandemic and seasonal influenza. Pandemic (H1N1) 2009 briefing note 20. 22 December 2009. Available from: http:// www.who.int/csr/disease/swineflu/notes/briefing_20091222/ en/index.html

47. Reed C, Angulo FJ, Swerdlow DL, Lipsitch M, Meltzer MI, Jernigan D, et al. Estimates of the prevalence of pandemic (H1N1) 2009, United States, April-July 2009. Emerg Infect Dis. 2009;15(12):2004-7.

48. World Health Organization (WHO). International health regulations (2005), 2nd ed. Geneva: WHO; 2008. Available from: http://whqlibdoc.who.int/ publications/2008/9789241580410_eng.pdf

49. Council of the European Union. Council conclusions on Lessons learned from the $\mathrm{A} / \mathrm{H}_{1} \mathrm{~N}_{1}$ pandemic - Health security in the European Union. 3032nd General Affairs Counci meeting. Brussels, 13 September 2010. Available from: http://ec.europa.eu/health/preparedness response/docs/ council_lessonsh1n1_en.pdf 